\title{
EFEKTIFITAS MEDIA PEMBELAJARAN BERKONSEP GAMIFIKASI PENGENALAN TATA SURYA MATA PELAJARAN IPA TERPADU KELAS VII DI SMP NEGERI 2 KUBUTAMBAHAN
}

\author{
I B Kade Merta Sudana ${ }^{1)}$, P Wayan Arta Suyasa ${ }^{2}$, Ketut Agustini ${ }^{3)}$ \\ ${ }^{123}$ Fakultas Teknik dan Kejuruan. Universitas Pendidikan Ganesha. Singaraja. Bali \\ e-mail: gus.merta281198@gmail.com¹.arta.suyasa@undiksha.ac.id². ketutagustini@undiksha.ac.id ${ }^{3}$
}

\begin{abstract}
ABSTRAK
Tujuan dari penelitian ini yaitu untuk mengembangkan sebuah media pembelajaran animasi dua dimensi yang dipadukan dengan konsep gamifikasi yang di dalam proses pembelajaran akan membantu menjelaskan hal - hal yang abstrak dan memberikan gambaran yang realistik mengenai materi yang akan diajarkan sekaligus menambah pemahaman dan motivasi kepada peserta didik untuk mengikuti pembelajaran disamping itu dengan adanya konsep gamifikasi membuat suasana belajar lebih menyenangkan khususnya pada mata pelajaran ilmu pengetahuan alam yaitu materi tata surya kelas VII di SMP Negeri 2 kubutambahan. Pengembangan media pembelajaran ini menggunakan jenis penelitian Research and Development $(R \& D)$ dan menggunakan metode Multimedia Development Life Cycle (MDLC). Beberapa pengujian dilakukan untuk mengetahui tingkat kefektifan media pembelajaran berkonsep gamifikasi, yang diantaranya ialah uji Ahli isi dengan hasil presensate $100 \%$, uji ahli media diperoleh $100 \%$, uji efektifitas diperoleh presentase keberhasilan $78,97 \%$ yang termasuk dalam kretiria tinggi, uji respon guru $90 \%$ dan untuk uji respon siswa diperoleh presentase $83,25 \%$ yang termasuk dalam kriteria baik.
\end{abstract}

Kata Kunci : Gamifikasi, Metode MDLC, Tata Surya

\begin{abstract}
The purpose of this study is to develop a two-dimensional animated learning media that is combined with the gamification concept which in the learning process will help explain things that are abstract and provide a realistic overview of the material that will help improve understanding and motivation for students in participate in learning besides that with the concept of gamification makes learning more fun especially in the natural sciences in the solar system class VII in junior high school 2 Kubutambahan. In the development of instructional media, this type of research uses Research and Development (R\&D) and uses the Multimedia Development Life Cycle (MDLC) method. Some tests were carried out to know the effectiveness of learning media with gamification concept, which tested content expert with $100 \%$ results, media expert test was obtained $100 \%$, effectiveness test was obtained successful percentage of $78.97 \%$ which included as high criteria, $90 \%$ teacher response test and for student response test obtained a percentage of $83.25 \%$ which was included as good criteria.
\end{abstract}

Keywords: Gamification, MDLC method, solar system

\section{PENDAHULUAN}

IImu Pengetahuan Alam adalah istilah yang digunakan yang merujuk pada rumpun ilmu di mana obyeknya adalah benda-benda alam dengan hukum-hukum yang pasti dan umum, berlaku kapan pun dan di mana pun. Pembelajaran IImu Pengetahuan Alam (IPA) berfungsi untuk memberikan pengetahuan 
tentang lingkungan alam disekitar, salah satu materi yang ada di pembelajaran IImu pengetahuan alam yang membutuhkan gambaran yang realistik yaitu materi Tata Surya dimana materi ini penanamkan pemahaman tentang model system tata surya, mengidentifikasi anggota tata surya, mengidentifikasi dampak rotasi dan revolusi bumi, mengetahui terjadinya siang dan malam. Beberapa pemahaman tentang materi tata surya seharusnya materi tersebut diajarkan dengan maksimal baik dalam proses pembelajaran di sekolah mengingat pentingnya materi tersebut seperti yang telah diungkapkan diatas. Tata surya adalah susunan benda-benda langit yang terdiri atas matahari sebagai pusatnya planet-planet, meteorid, komet, serta asteroid yang mengelilingi matahari. Susunan tata surya terdiri atas matahari, delapan planet, satelitsatelit pengiring planet dan benda langit lainnya dalam mengelilingi matahari disebut revolusi. Sebagian besar garis edarnya (orbit) berbentuk elips. Matahari merupakan pusat tata surya yang berupa bola gas yang bercahaya[1].

Berdasarkan pada hasil observasi dan wawancara yang dilaksanakan pada tanggal 23 september 2019 di SMP Negeri 2 Kubutambahan, Desa Tamblang Kecamatan Kubutambahan, pada siswa kelas 7 dan juga dengan guru pengampu yang bernama lbu Ni Wayan Resiadi, S.Pd.Fis. Dari observasi dan wawancara yang didapat masih ada kekurangan dalam hal mengajar diantaranya didalam pembelajaran IPA di materi sistem tata surya, dalam menjelaskan materi guru masih menggunakan hal-hal yang absrak dan juga siswa masih menggunakan metode membaca dan menghafal yang monoton dalam menerima pembelajaran di kelas disamping itu kurangnya media pembelajaran yang digunakan pada saat proses pembelajaran. Metode yang digunakan oleh guru selama proses pembelajaran adalah ceramah dan penugasan, hal ini menyebabkan pembelajaran berlangsung secara monoton dan membuat siswa bosan dan kurang memperhatikan pelajaran yang sedang disampaikan. Sebagian siswa kurang antusias dalam mengikuti pelajaran, hal ini dibuktikan dengan tidak ada respon dari peserta didik dalam proses pembelajaran. [2], Faktor utama yang menyebabkan rendahnya mutu pembelajaran IPA tersebut adalah kurang tepatnya pemilihan media pembelajaran oleh guru.

Permasalahan yang terjadi diatas, penulis dapat memberikan solusi yaitu sebuah media pembelajaran animasi dua dimensi dalam mata pelajaran IPA Terpadu khususnya materi Tata Surya yang akan dikombinasikan dengan konsep permainan.Di dalam perancangan media pembelajaran ini, penulis menggabungkan dua media atau lebih yaitu teks, grafik, gambar, audio, video dan animasi menjadi satu yang akan dikombinasikan dengan konsep gamifikasi yang akan merefleksi pikiran peserta didik dengan cara bermain sehingga proses pembelajaran tidak menjadi membosankan. Dalam perancangan media pembelajaran ini dikombinasikan dengan konsep gamifikasi yang merupakan konsep dalam pembelajaran dengan menggunakan prinsip permainan. Metode gamifikasi ialah pelaksanaan tata cara serta strategi dari suatu game ke dalam konteks nonpermainan untuk menuntaskan masalah untuk menggapai suatu tujuan ini pula sangat cocok bila diterapkan pada kurikulum 2013, dikarenakan konsep gamifikasi ini bertujuan untuk pendekatan sainfik yang mana peserta didik dapat mengamati materi dengan melihat gambar, menalar, menanya, mengolah data serta mengkomunikasikan gambar yang terdapat di dalam media pembelajaran berkonsep gamifikasi pada materi tata surya [3],[4],[5]. Media pembelajaran ialah alat- alat pendukung ataupun perantara buat mengantarkan informasi berbentuk materi pembelajaran sehingga memudahkan peserta didik menguasai apa yang disampaikan oleh guru [6]. Oleh karena itu, peneliti mencoba mengembangkan media pembelajaran dengan mengkombinasikan dengan konsep gamifikasi khususnya dalam mata pelajaran IPA Terpadu materi tata surya di Sekolah Menengah Pertama.

\section{METODE}

Model pengembangan yang digunakan dalam penelitian ini adalah Metode Multimedia Development Life Cycle (MDLC) yang terdiri dari 6 tahapan, yaitu Concept, Design, Material collecting, Assembly, Testing, dan Distribution. Keenam tahap ini tidak harus berurutan dalam praktiknya, tahap-tahap tersebut dapat saling bertukar posisi. Meskipun begitu, tahap concept memang harus menjadi hal yang pertama kali dikerjakan. 


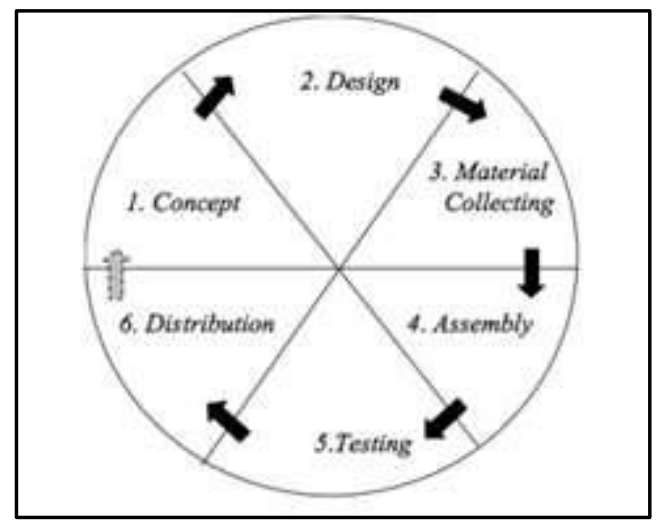

Gambar 1. Tahapan model MDLC Sumber : (Mustika, 2018)

\section{A. Concept (Pengonsepan)}

Tahap Concept (pengonsepan) adalah untuk menentukan tujuan dan siapa pengguna program (identifikasi audiensi). Tahap concept merupakan tahap awal dari pengembangan multimedia. Kegiatan dalam tahap ini adalah menentukan sebuah tujuan, jenis, konsep media, materi pelajaran, kegunaan dan sasaran pengguna dari pembuatan aplikasi multimedia. Secara umum proses pada tahap konsep adalah menentukan tujuan media pembelajaran, menentukan konsep materi pembelajaran, menentukan konsep isi media pembelajaran.

\section{B. Design (Perancangan)}

Pada tahap ini membuat spesifikasi secara rinci mengenai arsitektur proyek, gaya, tampilan, dan kebutuhan material/bahan untuk program. Tahap ini biasanya menggunakan storyboard untuk menggambarkan deskripsi tipe scene, hal tersebut bertujuan agar pembuatan media pembelajaran lebih terarah dan tertata dengan cara mencantumkan semua objek media pembelajaran dan tautan dari scene ke scene lain. Perancangan storyboard meliputi bentuk visual, suara, keterangan dan narasi akan dibuat. Pada pengembangan media pembelajaran ini akan dipadukan dengan sebuah konsep gamifikasi, pada penerapan gamifikasi menggunakan Achiever Mechanics pada Marczewski's Gamefication Framework[7].

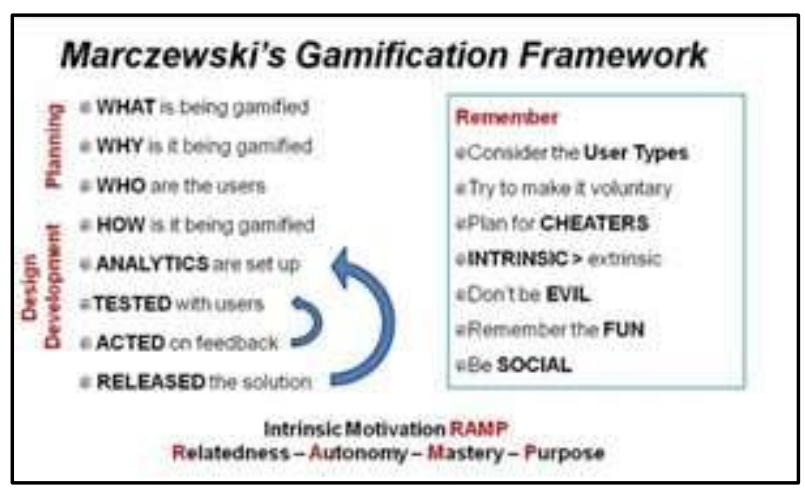

Gambar 2. Marczewski's Gamification Framework Sumber: (Darnanta, 2019)

\section{Material Collection (Pengumpulan Bahan)}

Tahap ini yaitu pengumpulan bahan, bahan yang dikumpulkan berbentuk teks, gambar, animasi, suara serta mengumpulkan materi dan soal- soal yang hendak ditampilkan di dalam media pembelajaran, bahan yang diperoleh untuk kebutuhan aplikasi dari membuat sendiri dengan memanfaatkan perangkat lunak Adobe llustrator CS6, Adobe Flash Profesional CS6 serta Adobe Audition CS6. Asembly 


\section{Assembly (Pembuatan)}

Tahap assembly adalah tahap dimana seluruh objek seperti teks, gambar, audio, dan material lainnya yang telah dikumpulkan sebelumnya dibuat menjadi sebuah media pembelajaran yang tersusun dalam satu kesatuan yang utuh sesuai dengan story board yang telah dirancang.

\section{E. Testing (Pengujian)}

Tahap Testing adalah tahap untuk melakukan pengujian pada media pembelajaran yang dibuat, tahap ini dilakukan agar mengetahui adanya error pada media pembelajaran yang dibuat. penelitian ini dilakukan dalam dua tahap yaitu pengujian alpha dan pengujian beta. Pengujian alpa terdiri dari validasi uji ahli isi dan uji ahli media sedangkan pengujian beta terdiri dari validasi perorangan, validasi kelompok kecil, validasi lapangan selanjutnya dilanjutkan dengan uji efektifitas dan uji respon guru.

\section{F. Distribution}

Distribution adalah tahap aplikasi selesai dibuat, aplikasi di-export menjadi file *.exe, agar aplikasi tersebut dapat dijalankan dengan mudah di perangkat computer dan disimpan dalam suatu media penyimpanan seperti Flashdisk, dan CD yang sebelumnya sudah dijadikan file autoplay. Tahap pendistribusian termasuk dalam tahap evaluasi karena adanya evaluasi sangat dibutuhkan untuk mengembangkan produk yang sudah dibuat sebelumnya agar mejadi lebih baik. Tahap ini merupakan tahap akhir dimana media telah siap didistribusikan di sekolah.

\section{HASIL DAN PEMBAHASAN}

\section{A. Hasil Implementasi}

Pada Penelitian pengembangan ini produk yang dihasilkan adalah media pembelajaran berkonsep gamifikasi pengenalan tata surya mata pelajaran IPA terpadu kelas VII di SMP Negeri 2 Kubutambahan. Pembuatan media pembelajaran ini diawali dengan mendesain tampilan dengan menggunakan Adobe Flash CS6. Kemudian diberikan action script agar media pembelajaran dapat berjalan sesuai dengan yang diharapkan dan dapat menunjang fungsionalitas serta interaktifitas media. Pembuatan media ini didukung dari berbagai software lainya seperti Adobe llustrator, Adobe After Effect untuk membuat karakter animasi dan Adobe Audition untuk memberikan dubbing suara dalam media pembelajaran. Jika semua desain selesai, berikutnya memasukkan action script agar media pembelajaran dapat berjalan sesuai dengan yang diharapkan. Media pembelajaran ini terdiri dari Tampilan Awal, Beranda, Pendahuluan, Indikator Pembelajaran, Materi, Game Kuis dan Profil. Adapun hasil pembuatan media adalah sebagai berikut:

1. Tampilan Awal Media Pembelajaran

Tampilan awal atau judul merupakan halaman yang akan muncul ketika media pembelajaran dijalankan. Tampilan dimulai dengan animasi teks serta animasi sebuah planet bumi yang di tengah planet berisi tombol start.

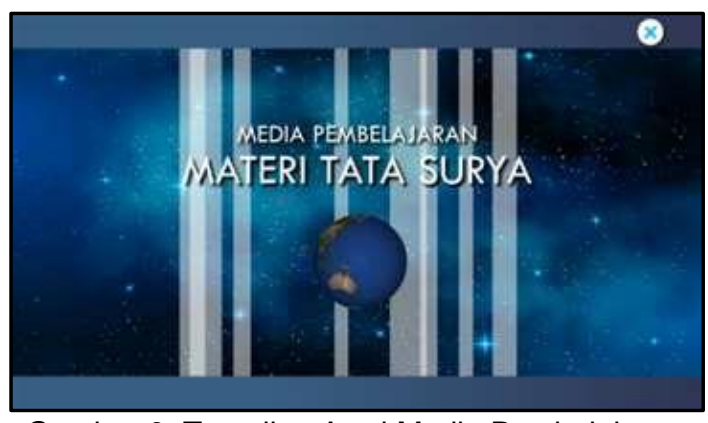

Gambar 3. Tampilan Awal Media Pembelajaran

2. Tampilan Halaman Beranda

Pada halaman beranda media pembelajaran ada menu indicator, materi pelajaran, serta profil 
pengembang. Pada bagian pojok kanan atas terdapat tombol untuk menutup ataupun mengakhiri media pembelajaran, tombol volume digunakan untuk mematikan serta menghidupkan backsound.

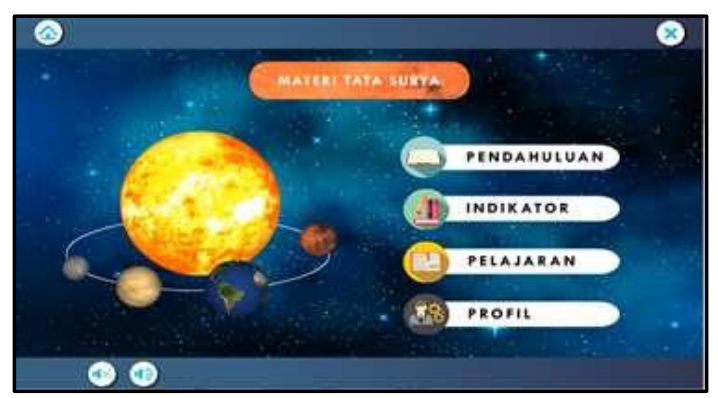

Gambar 4. Tampilan Utama Media Pembelajaran

3. Tampilan Halaman Pendahuluan

Pada menu pendahuluan terdiri dari submenu kata pengantar, dan petunjuk tombol. Submenu kata pengantar memuat tentang penjelasan singkat media pembelajaran, petunjuk tombol memuat tentang fungsi masing-masing tombol pada media pembelajaran untuk mempermudah pengguna dalam pengoperasian media pembelajaran.

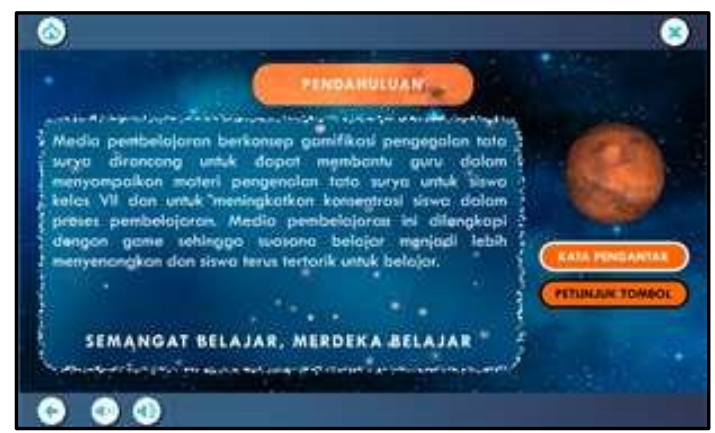

Gambar 5. Tampilan Halaman Pendahuluan

4. Tampilan Halaman Indikator

Pada halaman ini dalah halaman indikator yang berisi apa yang ingin dicapai dari sebuah pembelajaran

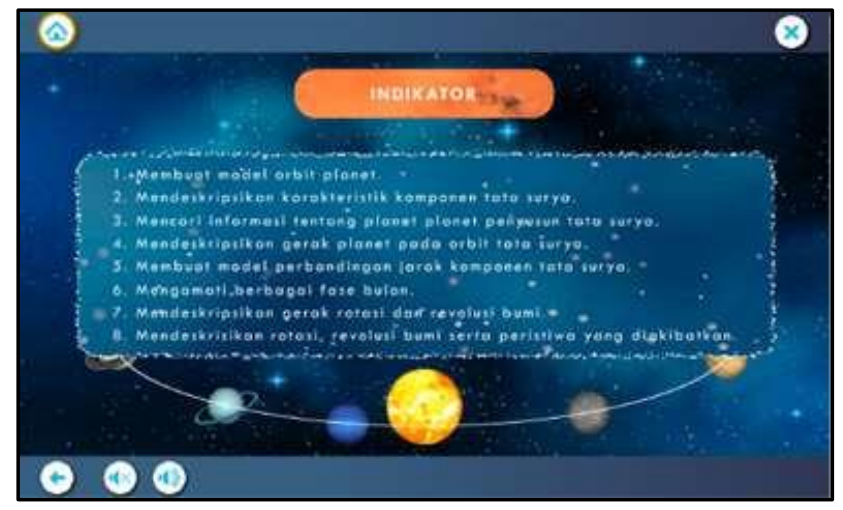

Gambar 6. Tampilan Halaman Indikator 


\section{Tampilan Menu Materi Pembelajaran}

Menu materi terdiri dari 7 pokok submateri yakni: (1) submenu mengenal karakteristik tata surya untuk menuju ke halaman isi materi yang menjelaskan isi dari tata surya diantara planet-planet, asteroid, meteoroid, dan komet, (2) submenu mengenal planet dalam dan luar untuk menuju ke halaman isi materi planet dalam dan luar, (3) submenu mengetahui jarak planet dengan matahari untuk menuju ke halaman materi jarak planet dengan matahari, (4) submenu revolusi dan rotasi bumi memiliki fungsi untuk menuju ke halaman isi materi yang menjelaskan revolusi dan rotasi bumi dalam tata surya (5) sub menu gerhana matahari untuk halaman materi gerhana matahari, (6) sub menu gerhana bulan untuk ke halaman materi gerhana bulan, (7) submenu yang selanjutnya yaitu mengenal fase-fase bulan untuk menuju ke halaman isi materi yang menjelaskan fase-fase bulan

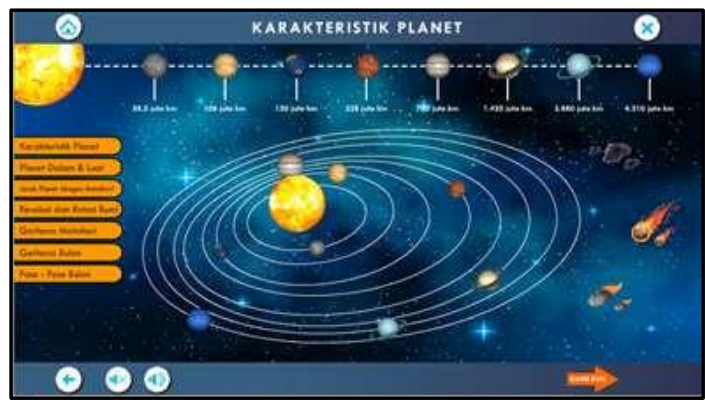

Gambar 7. Tampilan Halaman Materi Pembelajaran

\section{Tampilan Game Kuis}

Halaman awal pada halaman Game Kuis terdiri dari pilihan ganda, tebak gambar, urut planet, isian. Halaman pilihan ganda, tebak gambar, isian masing-masing berisikan 10 soal dan urut planet berisikan planet-planet yang sudah diacak dan diurutkan sesuai dengan ketentuan. Jika jawaban benar atau salah akan dihitung dan mendapatkan nilai setelah selesi menjawab soal. Di akhir pengerjaan soal akan muncul point atau badges beserta feedback. Pada halaman ini juga terdapat tombol coba lagi untuk kembali mengulangi mengerjakan soal game kuis. 


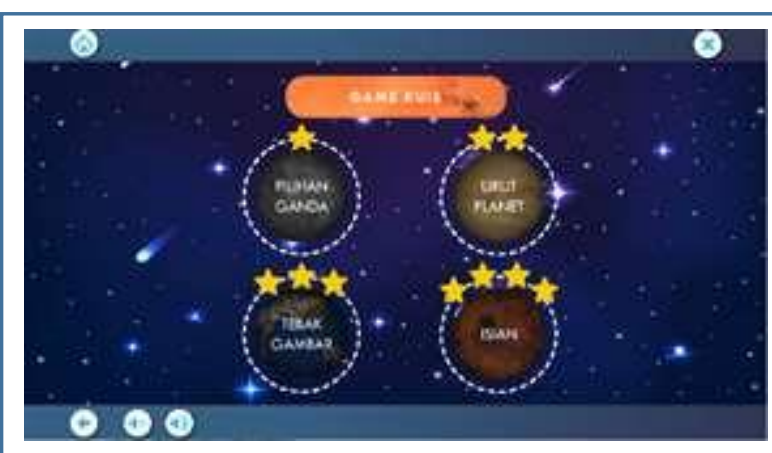

Tampilan Halaman Utama Game Kuis

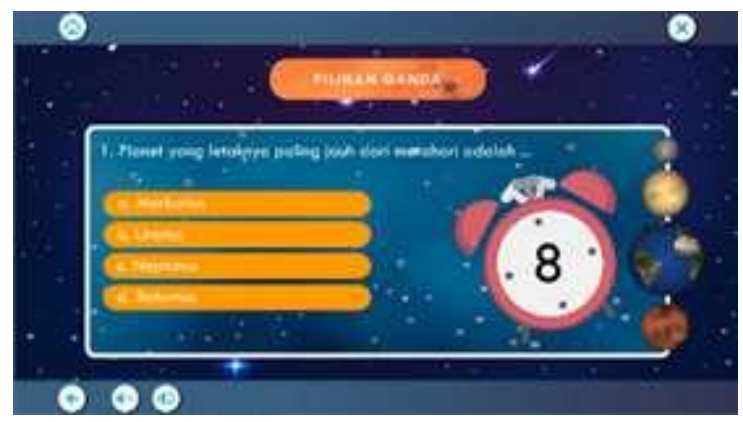

Tampilan Game Kuis Pilihan Ganda

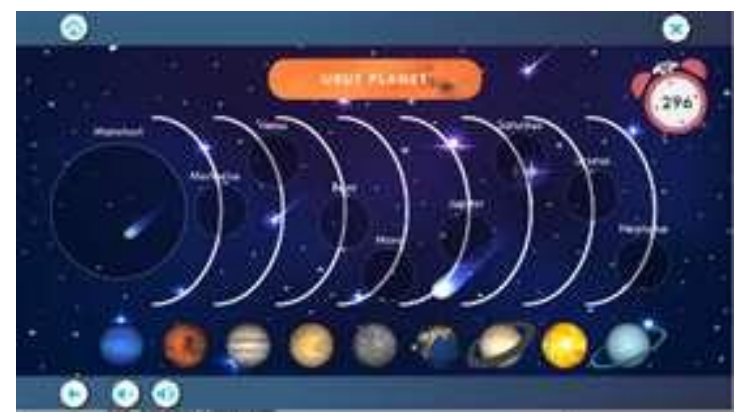

Tampilan Game Kuis Urut Planet

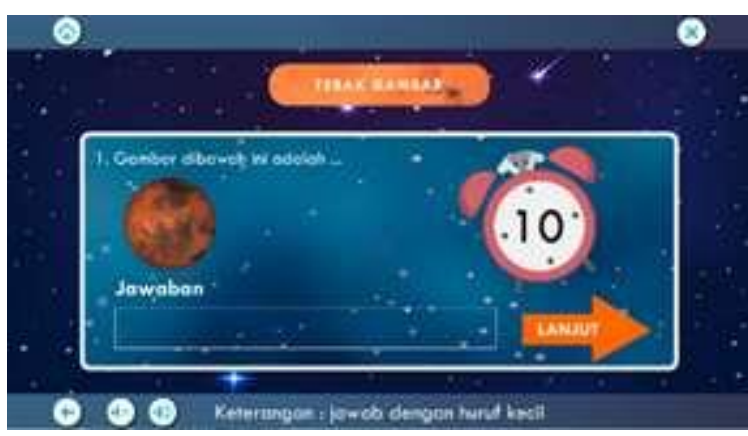

Tampilan Game Kuis Tebak Gambar

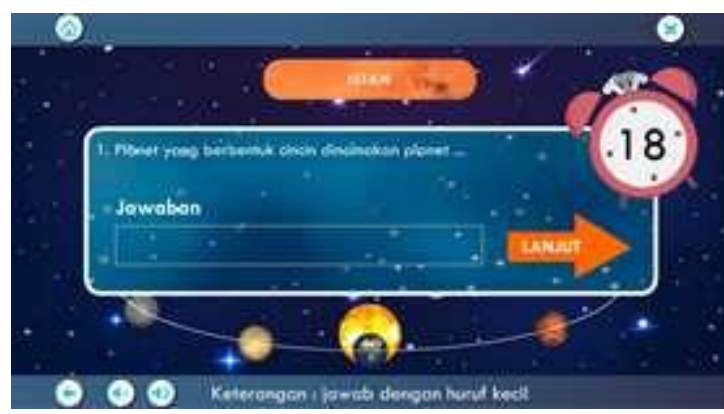

Tampilan Game Kuis Isian

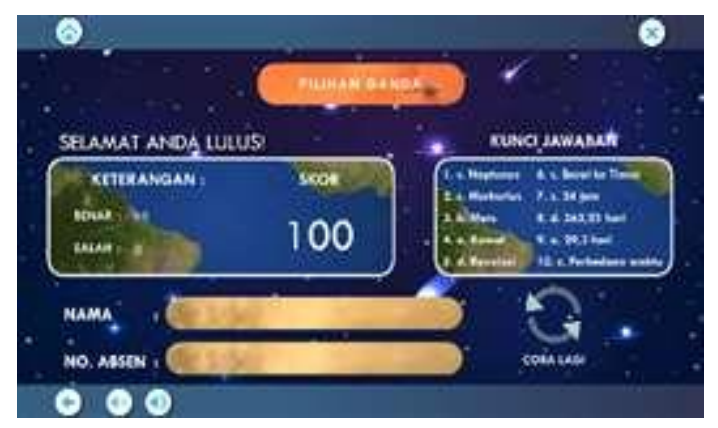

Tampilan Game Kuis Isian

Gambar 8. Tampilan Game Kuis

\section{Tampilan Menu Profil}

Halaman profil terdapat profil pengembang serta profil pembimbing. Pada halaman pengembang terdapat identitas pembuat media pembelajaran, dan profil pembimbing terdapat identitas pembimbing. 


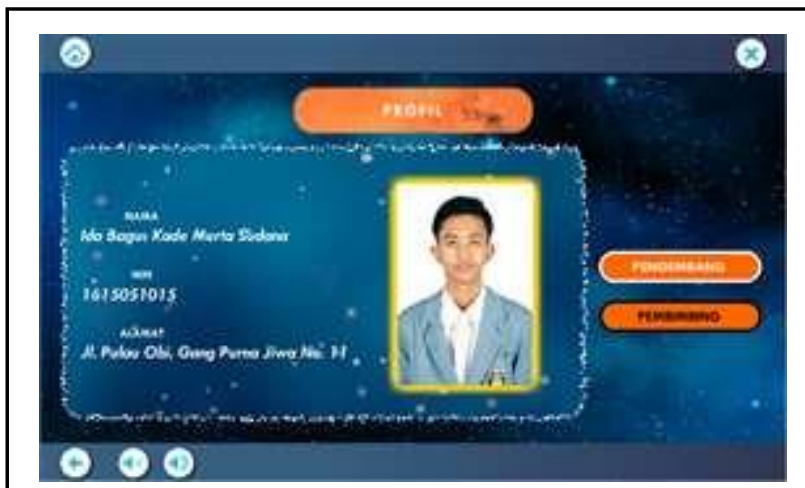

Tampilan Profil Pengembang

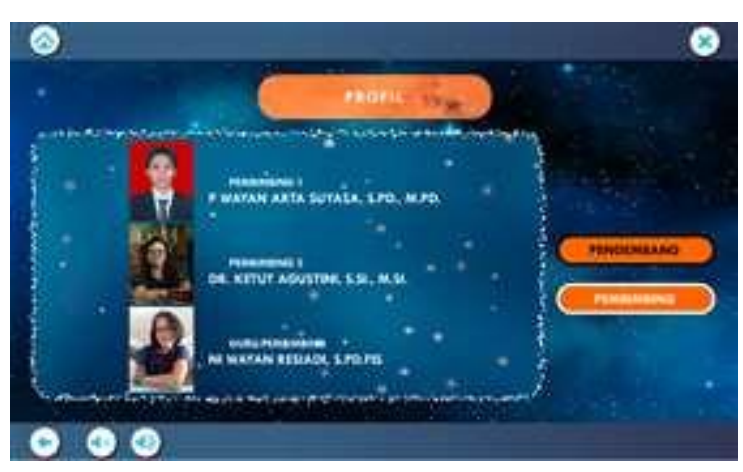

Tampilan Profil Pembimbing

Gambar 9. Tampilan Profil Pengembang dan

Pembimbing

\section{B. Hasil Pengujian}

Hasil Pengujian "Pengembangan Media Pembejaran Berkonsep Gamifikasi Pengenalan Tata surya Mata Pelajaran IPA Terpadu Kelas VII di SMP Negeri 2 Kubutambahan" terdapat uji ahli isi, uji ahli media, uji respon siswa dan uji respon guru.

\section{Uji Ahli Isi}

Kegiatan uji ahli isi ini bertujuan untuk mendapatkan data penelitian, pendapat, dan saran terhadap keseluruhan isi yang terdapat pada media pembelajaran berkonsep gamifikasi pengenalan tata surya yang telah dikembangkan. Uji ahli isi materi melibatkan 2 orang ahli, memperoleh hasil :

$$
\text { Validitas ahli isi }=\frac{D}{A+B+C+D}=\frac{10}{0+0+0+10}=\frac{10}{10}=1,00
$$

Produk pengembangan media pembelajaran berkonsep gamifikasi pengenalan tata surya memperoleh tingkat pencapaian "Sangat Tinggi", maka dapat disimpulkan bahwa tingkat pencapaian isi dari media pembelajaran berkonsep gamifikasi pengenalan tata surya adalah "Sangat Tinggi". Hal tersebut mengidikasikan bahwa media pembelajaran berkonsep gamifikasi Pengenalan Tata Surya layak untuk digunakan dalam pembelajaran ilmu pengetahuan alam materi tata surya.

\section{Uji Ahli Media}

Kegiatan uji ahli media pembelajaran ini bertujuan untuk mendapatkan data penelitian, pendapat, dan saran terhadap pengembangan media yang digunakan pada mata pelajaran ilmu pengetahuan alam yang telah dikembangkan. Uji ahli media pembelajaran melibatkan dua dosen dari prodi pendidikan teknik informatika, hasil uji ahli media memperoleh hasi :

$$
\text { Validitas ahli media }=\frac{D}{A+B+C+D}=\frac{10}{0+0+0+10}=\frac{10}{10}=1,00
$$

Produk pengembangan media pembelajaran berkonsep gamifikasi pengenalan tata surya memperoleh tingkat pencapaian "Sangat Tinggi", maka dapat disimpulkan bahwa tingkat pencapaian media pembelajaran berkonsep gamifikasi pengenalan tata surya adalah "Sangat Tinggi". Hal tersebut 
mengidikasikan bahwa media pembelajaran berkonsep gamifikasi Pengenalan Tata Surya layak untuk digunakan dalam pembelajaran ilmu pengetahuan alam materi tata surya.

\section{Uji Respon}

Uji Respon siswa terhadap media pembelajaran dilakukan dengan cara mengguakan angket yang disebar dalam tiga kategori pengujian yaitu :

\section{a. Uji Respon Perorangan}

Uji respon perorangan bertujuan untuk mengetahui apakah media pembelajaran yang dikembangkan dapat meningkatkan konsentrasi belajar siswa terhadap proses pembelajaran konten Tata Surya. Peneliti menyebar angket kepada 3 orang siswa kelas VIIB SMP Negeri 2 Kubutambahan dengan tingkat prestasi berbeda yaitu, tingkat prestasi rendah, sedang dan tinggi. Hal ini ditentukan oleh guru yang bersangkutan. Proses mengoperasikan media pembelajaran ini dan penyebaran angket terhadap siswa maka peneliti mendapatkan data hasil uji coba respon perorangan kemudian dapat disimpulkan bahwa media pembelajaran berkonsep gamifikasi pengenalan tata surya dikatakan berhasil atau positif dalam mendukung proses pembelajaran dengan hasil presentase masing-masing memberikan tanggapan baik dan sangat baik dengan rata-rata penilaian ketiga orang siswa adalah $86 \%$. Apabila presentase tersebut dikonversikan ke dalam tabel tingkat hasil penilaian skala linkert masuk dalam kategori "baik".

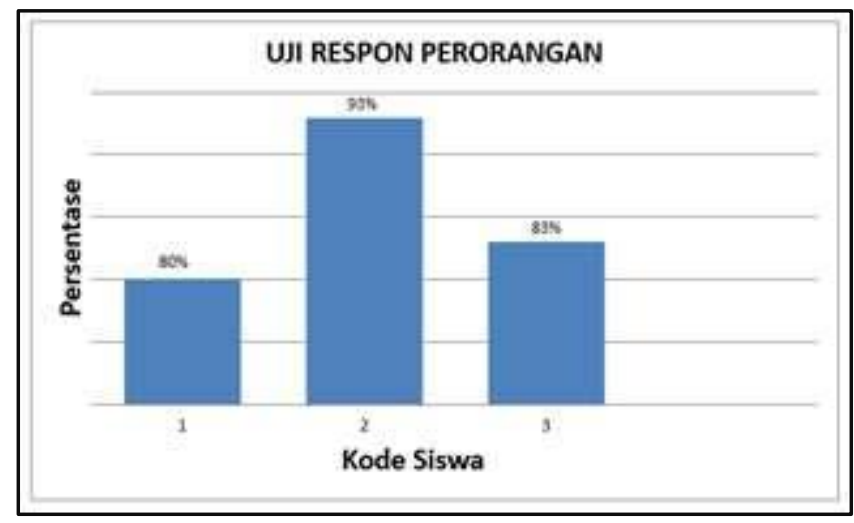

Gambar 10. Uji Respon Perorangan

b. Uji Kelompok Kecil

Pengujian kelompok kecil dilakukan oleh siswa sebanyak 8 orang kelas VIIB SMP Negeri 2 Kubutambahan berdasarkan tingkat pengetahuan yaitu siswa dengan prestasi belajar tinggi, siswa dengan prestasi belajar sedang, dan siswa dengan prestasi belajar rendah hal tersebut ditentukan oleh guru yang bersangkutan.

Proses mengoperasikan media pembelajaran ini dan penyebaran angket terhadap siswa maka peneliti mendapatkan data hasil uji coba responden kelompok kecil kemudian dapat disimpulkan bahwa media pembelajaran berkonsep gamifikasi pengenalan tata surya dikatakan berhasil atau positif dalam mendukung proses pembelajaran dengan hasil presentase masing-masing memberikan tanggapan baik dan sangat baik dengan rata-rata penilaian delapan orang siswa adalah $87,125 \%$. Apabila presentase tersebut dikonversikan ke dalam tabel tingkat hasil penilaian skala linkert masuk dalam kategori "baik". 


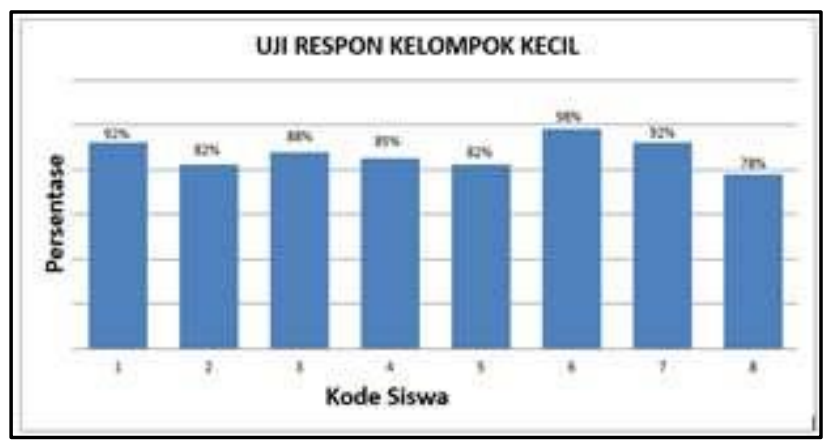

Gambar 11. Uji Respon Kelompok Kecil

\section{c. Uji Respon Lapangan}

Uji respon lapangan dilakukan oleh siswa sebanyak 20 orang kelas VIIA SMP Negeri 2 Kubutambahan. Pada uji respon lapangan media pembelajaran di uji coba oleh siswa secara keseluruhan dan setiap siswa yang dijadikan responden dan diberikan instrumen angket penilaian produk media pembelajaran. Dari proses mengoperasikan media pembelajaran ini dan penyebaran angket terhadap siswa maka peneliti mendapatkan data hasil uji coba responden lapangan kemudian dapat disimpulkan bahwa media pembelajaran berkonsep gamifikasi pengenalan tata surya dikatakan berhasil atau positif dalam mendukung proses pembelajaran dengan hasil presentase masing-masing memberikan tanggapan baik dan sangat baik dengan rata-rata penilaian Sembilan orang siswa adalah $83,25 \%$. Apabila presentase tersebut dikonversikan ke dalam tabel tingkat hasil penilaian skala linkert masuk dalam kategori "baik".

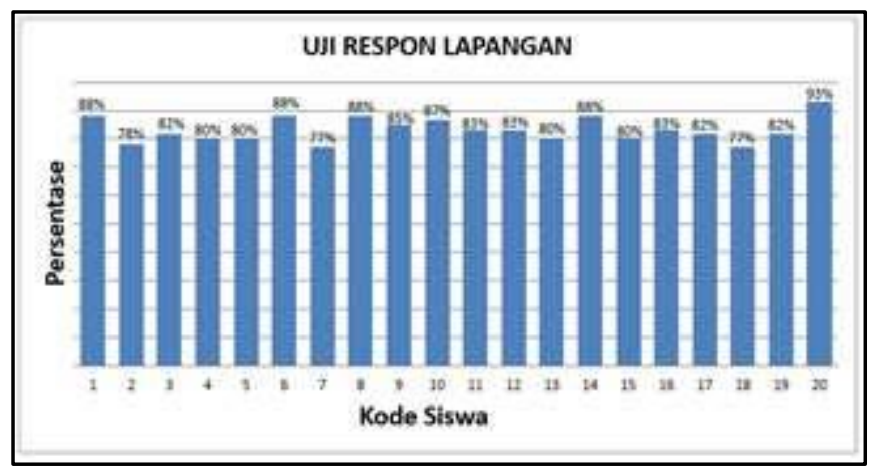

Gambar 12. Uji Respon Lapangan

Hasil penelitian pengembangan media pembelajaran berkonsep gamifikasi pengenalan tata surya mata pelajaran IPA terpadu kelas VII di SMP Negeri 2 Kubutambahan sejalan dengan penelitian yang dilakukan oleh [8], dengan judul penelitian "Pengembangan Media Pembelajaran IPA Berbasis Macromedia Flash 8 Materi Pencemaran Lingkungan untuk Siswa SMP Kelas VII", dengan uji respon siswa, siswa diberikan angket untuk mengetahui penilaian mereka terhadap media yang dikembangkan. Respon siswa pada uji coba lapangan termasuk dalam kategori baik dengan rata-rata $83,25 \%$ siswa memberikan respon positif.

\section{Uji Efektifitas}

Uji efektifitas ini dilakukan dengan pemberian pretest dan posttest untuk mengetahui peningkatan hasil belajar siswa setelah menggunakan media pembelajaran. peneliti menyebarkan angket pretest sebelum dilakukan pembelajaran menggunakan media dan setelah melakukan proses belajar peneliti kembali membagikan angket uji posttest pada siswa, uji efektifitas dilakukan oleh siswa sebanyak 20 orang siswa kelas VIIA SMP Negeri 2 Kubutambahan. Hasil analisis pretest dan posttest tersebut didapatkan rata-rata persentase kenaikan nilai sebesar $78,97 \%$. sehingga tingkat kenaikan hasil posttest masuk ke kriteria "Tinggi" yang berarti media ini efektif untuk diterapkan dalam proses pembelajaran ilmu pengetahuan alam materi tata surya. 
Hasil penelitian ini juga mendukung penelitian terdahulu yang dilakukan oleh [9], yang berjudul "Pengembangan Media Interaktif Pengenalan Sistem Tata Surya Menggunakan Framework MDLC". Hasil dari penelitian ini yaitu media interaktif yang dibuat berpengaruh positif bagi keaktifan peserta didik, terbukti dari adanya rata-rata mean dan pretest dan posttest sebesar 15.238 atau sebesar $22,27 \%$ dan dapat disimpulkan bahwa media pembelajaran interaktif layak untuk digunakan.

\section{E. Uji Respon Guru}

Uji respon guru dilakukan oleh guru mata pelajaran ilmu pengetahuan alam di SMP Negeri Kubutambahan. Pada uji respon guru media pembelajaran di uji coba oleh guru secara keseluruhan. Proses mengoperasikan media pembelajaran ini peneliti mendapatkan data hasil uji coba responden guru kemudian dapat disimpulkan bahwa media pembelajaran berkonsep gamifikasi pengenalan tata surya dikatakan berhasil atau sangat positif dalam mendukung proses pembelajaran dengan hasil presentase sangat baik dengan rata-rata penilaian guru mata pelajaran ilmu pengetahuan alam di SMP Negeri 2 Kubutambahan adalah $90 \%$. Apabila presentase tersebut dikonversikan ke dalam tabel tingkat hasil penilaian skala linkert masuk dalam kategori "Sangat baik".

Hasil penelitian pengembangan media pembelajaran berkonsep gamifikasi pengenalan tata surya mata pelajaran IPA terpadu kelas VII di SMP Negeri 2 Kubutambahan sejalan dengan penelitian yang dilakukan oleh [10], dengan judul penelitian "Media Pembelajaran Matematika Berbasis Gamifikasi Bagi Pelajar SMP Kelas VIII" Metodologi yang digunakan pada penelitian ini dirancang dengan menggunakan framework gamifikasi Marczewsky.

\section{SIMPULAN DAN SARAN}

Berdasarkan pemaparan hasil penelitian "Pengembangan Media Pembelajaran Berkonsep Gamifikasi Pengenalan Tata Surya Mata Pelajaran IPA Terpadu Kelas VII di SMP Negeri 2 Kubutambahan" dapat disimpulkan bahwa implementasi media pembelajaran berkonsep gamifikasi pengenalan tata surya kelas VII menggunakan model Multimedia Development Life Cycle (MDLC) yang memiliki enam tahapan concept (pengonsepan), design (perancangan), material collection (pengumpulan bahan), assembly (pembuatan), testing (pengujian), dan distribution (pendistribusian). Respon siswa terhadap media pembelajaran berkonsep gamifikasi pengenalan tata surya dari proses mengoperasikan media pembelajaran ini dan penyebaran angket terhadap siswa maka peneliti mendapatkan data hasil uji coba respon perorangan, uji respon kelompok dan uji respon lapangan memberikan tanggapan baik, yaitu hasil presentase uji respon perorangan sebanyak $86 \%$ kemudian uji respon kelompok kecil sebanyak $87,125 \%$ dan uji respon lapangan $83,25 \%$, dan mendapat tingkat uji efektifitas dari media pembelajaran berkonsep gamifikasi pengenalan tata surya yaitu $78,97 \%$ serta uji respon guru terhadap media pembelajaran berkonsep gamifikasi sebanyak 90\%. Jadi dapat disimpulkan Pengembangan media pembelajran berkonsep gamifikasi pengenalan tata surya mata pelajaran IPA Terpadu kelas VII di SMP Negeri 2 Kubutambahan positif untuk digunakan dan mendukung proses pembelajaran.

Berdasarkan hasil penelitian yang sudah dipaparkan sebelumnya, terdapat beberapa saran untuk peneliti yang melakukan penelitian selanjutnya yaitu media ini masih memiliki kekurangan pada fitur - fitur, belum adanya fitur pengaturan tinggi rendahnya suara (volume), sehingga pengembangan selanjutnya agar melengkapi fitur - fitur yang belum ada pada saat ini, Game kuis dengan menggunakan konsep gamifikasi masih berbentuk permainan sederhana, untuk pengembangan selanjutnya diharapkan mampu menambah level permainan dari yang ada sebelumnya agar lebih menarik perhatian kemudian penelitian selanjutnya dapat dilakukan jenis penelitian eksperimen.

\section{DAFTAR PUSTAKA}

[1] R. Damayanti, "PEGEMBANGAN MEDIA PEMBELAJARAN ULAR TANGGA UNTUK MEREMEDIASI SISWA KELAS VII PADA MATERI TATA SURYA," 2019.

[2] Y. I. Pratiwi, R. Budiharti, and E. Y. Ekawati, "PENGEMBANGAN MEDIA PEMBELAJARAN IPA TERPADU INTERAKTIF DALAM BENTUK MOODLE UNTUK SISWA SMP PADA TEMA MATAHARI SEBAGAI SUMBER ENERGI ALTERNATIF Yosmita Indri Pratiwi, Rini Budiharti, Elvin Yusliana Ekawati.," J. Pendidik. Fis., 2014.

[3] F. H. Romdhoni and R. P. Wibowo, "Penerapan Gamification Pada Aplikasi Interaktif Pembelajaran 
[4] H. Maryanto, M. Suyanto, and H. Al, "Penerapan Gamification Cashflow Sebagai Media Pembelajaran Pengelolaan Keuangan Pribadi Pada Anak Usia Dasar ( Studi Kasus : Sdn Plumpung 1 Plaosan Magetan )," Telematika, 2017.

[5] M. (Universitas N. Maulana, "Pengembangan Media Pembelajaran Berbasis Adobe Flash Pada Materi Hidrosfer Kelas X Sma Negeri 1 Kedungwuni Kabupaten Pekalongan Tahun 2013 / 2014," 2015.

[6] F. T. Nomleni and T. S. N. Manu, "Pengembangan Media Audio Visual dan Alat Peraga dalam Meningkatkan Pemahaman Konsep dan Pemecahan Masalah," Sch. J. Pendidik. dan Kebud., vol. 8, no. 3, pp. 219-230, 2018, doi: 10.24246/j.js.2018.v8.i3.p219-230.

[7] B. W. Sari, E. Utami, H. Al, B. W. Sari, E. Utami, and H. Al Fatta, "Pembelajaran Tenses Bahasa Inggris Berbasis Web," J. IIm. SISFOTENIKA, 2015.

[8] F. Nasirudin and L. Mawartiningsih, "Pengembangan Media Pembelajaran IPA Berbasis Macromedia Flash 8 Materi Pencemaran Lingkungan untuk Siswa SMP Kelas VII The Development of Science Learning Media Based on Macromedia Flash 8 Environmental Pollution Material for Junior High School Grade VII ," vol. 14, pp. 509-516, 2017.

[9] I. A. Astuti, A. Harwanto, and T. Hidayat, "Pengembangan Media Interaktif Pengenalan Sistem Tata Surya Menggunakan Framework MDLC," Eksplora Inform., vol. 8, no. 2, pp. 158-166, 2019, doi: 10.30864/eksplora.v8i2.220.

[10] S. W. Handani and T. P. P. Kusuma, "Perancangan Media Pembelajaran Matematika Berbasis Gamifikasi Bagi Pelajar SMP Kelas VIII," pp. 91-97, 2018. 